\title{
Pengaruh Motivasi Kerja Otonom dan Internal Locus of Control Terhadap Kinerja Karyawan dengan Employee Engagement Sebagai Variabel Mediasi
}

\author{
Muhammad Shollih Abdurrahman ${ }^{1}$ Ratno Purnomo ${ }^{2 *}$ \& Eling Purwanto Jati ${ }^{3}$ \\ Jurusan Manajemen, Universitas Jenderal Soedirman, Indonesia \\ *Email corresponding author : ano.purnomo@gmail.com
}

\begin{abstract}
Abstrak
Tujuan penelitian ini adalah untuk menganalisis pengaruh motivasi kerja otonom dan internal locus of control terhadap kinerja karyawan PDAM Tirta Satria dengan employee engagement sebagai variabel mediasi. Jumlah responden yang diambil dalam penelitian ini adalah 92 responden dengan menggunakan purposive sampling. Penelitian ini menggunakan metode survey dengan menggunakan pendekatan kuantitatif. Alat analisis yang digunakan dalam penelitian ini adalah Analisis regresi berganda dengan software SPSS. Berdasarkan hasil analisis, dapat disimpulkan bahwa motivasi kerja otonom dan internal locus of control berpengaruh positif terhadap kinerja karyawan dengan employee engagement sebagai variabel mediasi.
\end{abstract}

Kata Kunci : Kinerja karyawan, Motivasi kerja otonom, internal locus of control, employee engagement.

\begin{abstract}
The purpose of this study is to analyze the influence of Autonomous Work Motivation and Internal Locus of Control on PDAM Tirta Satria's Employee Performance with Employee Engagement as mediating variable. There were 92 employees chosen as respondent of the research by using purposive sampling method. This research using quantitative approach. Analysis tool used in this research is Multiple Regression with SPSS software. Based on the result of the analysis, it can be concluded that Autonomous Work Motivation and Internal Locus of Control has positif effect on PDAM Tirta Satria's Employee Performance with Employee Engagement sa a mediating variable.
\end{abstract}

Keywoard : Employee Performance, Autonomous Work Motivation, internal locus of control, employee engagement.

\section{PENDAHULUAN}

Kinerja merupakan hasil kerja secara kualitas dan kuantitas yang dicapai oleh seseorang karyawan dalam melaksanakan tugasnya sesuai dengan tanggung jawab yang diberikan kepadanya Pencapaian hasil dapat diukur melalui penilaian kinerja karyawan (Mangkunegara: 2011:67). Peningkatan kinerja karyawan secara secara terus menerus akan memberikan keuntungan positif bagi perusahaan. Vosloban, (2012) menyatakan hasil positif dari peningkatan level kinerja karyawan secara berlanjut dapat membuat perusahaan terus berkembang.

Kinerja karyawan secara umum di pengaruhi oleh faktor-faktor yang berasal dari eksternal individu seperti lingkungan kerja, rekan kerja, dukungan atasan dan internal individu seperti motivasi dan kepribadian. Salah satu faktor internal yang dapat mempengaruhi kinerja karyawan adalah motivasi kerja otonom. Ghafary et al., (2017) menyatakan bahwa motivasi kerja otonom berpengaruh dalam meningkatkan performa kerja karyawan. Deci, Olafsen dan Ryan (2017) menyatakan bahwa setiap orang mempunyai kebutuhan dasar psikologis yang yang mendorong orang untuk memenuhinya. Kebutuhan tersebut adalah kebutuhan atas kebebasan, 
kompetensi dan keterkaitan (Deci, Olafsen, dan Ryan, 2017). Motivasi kerja akan muncul secara otonom atau dengan sendirinya apabila kebutuhan tersebut terpuaskan sehingga mempengaruhi performa kerja dan kesejahteraan seorang karyawan (Guo, 2007).

Faktor internal lainya yang dapat mempengaruhi kinerja seseorang adalah kepribadian. Banyak jenis kepribadian telah dikemukakan oleh para ahli, salah satunya adalah locus of control yang terbagi menjadi dua yakni internal locus of control dan external locus of control (Rotter, 1966). Amalini, Musadieq, dan Afrianty (2016) membuktikan bahwa kepribadian internal locus of control berpengaruh positif secara signifikan dalam peningkatan kinerja karyawan. Rotter (1966) dalam Mihaela, Magdalena dan Loredana (2013) mengatakan internal locus of control merupakan anggapan bahwa semua yang terjadi dalam kehidupan seseorang berada dalam kendali orang itu sendiri. Karyawan yang memiliki internal locus of control yang tinggi cenderung percaya diri dengan kemampuanya dalam bekerja. Hal tersebut didukung oleh penelitian Chen dan Silverthrone (2008) yang menunjukan bahwa seseorang yang memiliki level internal locus of control yang tinggi mempunyai tingkat kinerja yang tinggi pula.

Faktor internal karyawan yang juga berperan penting dalam peningkatan kinerja karyawan sebagaimana internal locus of control dan motivasi kerja otonom adalah employee engagement. Ramadhan dan Sembiring (2014) menyatakan bahwa pada employee engagement dapat meningkatkan kinerja karyawan. Kahn (1990) menjelaskan definisi dari employee engagement dalam bekerja sebagai pemanfaatan secara totalitas anggota organisasi kedalam pekerjaan mereka, sehingga mereka mampu mengekspresikan diri dan berperan penuh melalui kemampuan kognitif, emosi maupun perilaku. Definisi tersebut menunjukkan bahwa employee engagement merupakan hal yang sangat penting bagi perusahaan.

Motivasi kerja otonom merupakan motivasi dari dalam diri yang membuat seseorang merasa berkesediaan, kemauan, dan pilihan (Ryan, Olafsen dan Deci, 2017). Motivasi kerja otonom memiliki dampak yang positif terhadap kinerja karyawan (Manganelli, et al., 2018). Internal locus of control juga terbukti berperan dalam meningkatkan kinerja karyawan (Amalini, Musadieq dan Afrianty, 2016) sebagaimana pengaruh employee engagement dalam meningkatkan kinerja karyawan (Ramadhan dan sembiring, 2014). Ryan dan Deci (2000) menyebutkan bahwa orang yang memiliki motivasi dari dalam diri yang kuat memiliki tingkat engagement yang tinggi dalam kegiatan yang berkaitan dengan pekerjaannya. Penelitian yang dilakukan Fleur (2016) oleh menyatakan bahwa internal locus of control memiliki hubungan yang signifikan terhadap employee engagement. Penelitian lain yang dilakukan oleh Wiedeman (2016) membuktikan motivasi kerja otonom juga memiliki dampak positif terhadap employee engagement sehingga kondisi karyawan yang ter-engage akan terus meningkatkan kinerjanya. Employee engagement dibuktikan mempunyai pengaruh mediasi pada hubungan personal resource (self efficacy dan model big five) terhadap kinerja karyawan. (Bhatti, Alshagawi, dan Jurahari, 2018). Penelitian ini mengangkat personal source lain yakni internal locus of control dan motivasi kerja otonom untuk membuktikan adanya pengaruh mediasi employee engagement pada hubungan motivasi kerja otonom dan internal locus of control terhadap kinerja.

\section{TINJAUAN PUSTAKA}

\section{Kinerja Karyawan}

Mathis dan Jackson dalam Ramadhan \& Sembiring, (2014) mendefinisikan kinerja karyawan sebagai apa yang dilakukan maupun tidak dilakukan oleh karyawan dalam mengemban pekerjaannya. Mathis dan Jackson menjelaskan bahwa kinerja terdiri dari kemampuan untuk mengerjakan, kerja keras untuk merealisasikan, dan dukungan dari organisasi. Kinerja karyawan merupakan hal yang sangat penting bagi sebuah perusahaan karena karyawan yang memiliki kinerja yang baik akan membuat perusahaan bekerja dengan baik dan sesuai dengan visi dan misi yang ditetapkan. Hal tersebut mendorong perusahaan perlu melakukan penilaian kinerja untuk mengukur kinerja karyawan. Perusahaan jasa membutuhkan kinerja karyawan yang optimal demi, memberikan pelayanan terhadap masyarakat. Penelitian ini menggunakan definis dan pengukuran Mathis dan Jackson untuk mengukur kinerja karyawan. 


\section{Motivasi Kerja Otonom}

Motivasi kerja otonom mempunyai karakter yang penuh kesediaan kemauan dan bebas (Deci et al., 2017). Motivasi ini dapat disebabkan oleh faktor intrinsik seseorang ketika kebutuhan psikologis dasar seperti kebebasan, kompetensi dan hubungan sosialnya di tempat kerja terpenuhi. Deci et al., (2017) memberikan contoh terkait dengan motivasi kerja otonom seperti ketika seseorang memahami nilai dan tujuan pekerjaan dengan baik, memiliki rasa kepemilikan terhadap pekerjaan tersebut, dan merasakan kebebasan yang diberikan saat bekerja maka akan timbul motivasi yang kuat dalam diri seseorang. Controlled motivation merupakan motivasi yang terpengaruh oleh faktor-faktor eksternal seperti target kerja, perolehan produksi dalam jangka waktu pendek, tekanan dan menghindari hukuman (Deci et al., 2017). Penelitian ini menggunakan pengukuran definisi dan Deci dan Ryan.

\section{Internal Locus of Control}

Internal locus of control merupakan keyakinan atau anggapan bahwa setiap kejadian yang terjadi pada seseorang merupakan hal yang bisa ia kendalikan. Studi tentang konsep locus of control dalam konteks bisnis telah dilakukan baik jenis locus of control external maupun internal. Hasil positif banyak ditemukan pada studi kepribadian ini khususnya jenis internal locus of control. Beberapa studi membuktikan bahwa konsep dari internal locus of control menguntungkan bagi perusahaan. Keuntungan yang diperoleh dari internal locus of control dibuktikan oleh Ng, Sorensen, \& Eby, (2006) yang menyatakan bahwa orang dengan tingkat internal locus of control yang dominan cenderung fokus untuk bersikap proaktif, optimis, percayadiri, dan bertanggung jawab terhadap sesuatu masalah yang dihadapi.

\section{Employee Engagement}

Kahn menyatakan employee engagement merupakan keadaan psikologis seseorang dalam sebuah pekerjaan yang meningkatkan hubunganya dengan rekan kerja, kehadiran diri (secara fisik, emosi, kognitif) dan peran penuh dalam pekerjaanya (Rich, Lepine, \& Crawford, 2010). Shuck \& Wollard, (2010) menyatakan bahwa employee engagement juga berperan secara tidak langsung dalam meningkatkan kepuasan pelanggan yang memberikan kontribusi dalam meningkatkan pendapatan perusahaan. Shuck \& Wollard, (2010) menambahkan orang memiliki tingkat employee engagement yang tinggi menunjukan tingkat komitmen afektif dan kontribusi lebih tinggi. Maslach, Schaufeli, \& Leiter, (2001) menemukan bahwa employee engagement merupakan lawan yang paling tepat bagi burnout karyawan. Karakteristik employee engagement adalah energi, keterelibatan dan keyakinan diri. Karakter tersebut berlawanan dengan karakteristik burnout yaitu kelelahan, sinisme, dan ketidak yakinan diri sehingga employee engagement merupakan lawan alami dari masalah burnout pada karyawan Maslach et al., (2001). Penelitian ini menggunakan definisi dan pengukuran dari Rich, Lepine dan Crawford.

\section{PERUMUSAN HIPOTESIS}

Deci et al., (2017) menyebutkan terdapat beberapa kebutuhan dasar psikologis dalam diri seseorang yang menyebabkan orang tersebut untuk berperilaku. Kebutuhan dasar tersebut adalah kebutuhan akan kebebasan dalam pekerjaan, kebutuhan untuk berkompetensi dan kebutuhan akan hubungan atau relasi yang baik di tempat kerja. Motivasi kerja otonom akan muncul pada diri seseorang jika kebutuhan-kebutuhan tersebut terpuaskan sehingga memunculkan karakter yang penuh kesediaan dan kemauan untuk bekerja (Deci et al., 2017). Kondisi tersebut merupakan hal yang sangat menguntungkan bagi perusahaan karena kesediaan dan kemauan yang dimiliki karyawan dalam menyelesaikan tugas mampu membuat mereka bekerja secara sukarela. Berdasarkan uraian tersebut penulis mengajukan hipotesis :

H1: Motivasi kerja otonom berpengaruh positif terhadap kinerja karyawan

Hubungan harmonis (relatedness) antar karyawan menjadi salah satu hal yang menjadi kebutuhan serta memberikan sumber motvasi dalam bekerja (Deci et al., 2017). Hubungan tersebut dapat menarik seseorang kedalam salah satu keadaan psikologis karyawan yakni rasa aman secara psikologis (phsycological safety) dalam pekerjaan maupun lingkungan. Keadaan tersebut akan timbul dalam diri seseorang apabila para karyawan mempunyai ikatan emosional yang tinggi diantara mereka sehingga lingkungan kerja terasa nyaman (Shuck \& Wollard, 2010). 
Hal ini dapat diwujudkan dengan motivasi kerja otonom (Deci et al., 2017) karena konsep motivasi kerja otonom mendorong seseorang untuk membangun relasi atau hubungan yang baik ditempat kerja. Wiedemann, (2016) membuktikan bahwa motivasi kerja karyawan berpengaruh positif terhadap employee engagement. Dorongan dari dalam diri berupa kebutuhan psikologis akan peningkatan kompetensi, kebebasan dan hubungan di tempat kerja dapat menimbulkan kondisi psikologis yang ter-engage pada seseorang (Wiedemann, 2016). Berdasarkan uraian tersebut penulis mengajukan hipotesis kedua yaitu :

H2: Motivasi kerja otonom berpengaruh positif terhadap employee engagement

Rotter dalam Mihaela, Magdalena, \& Loredana, (2013) menyatakan internal locus of control merupakan anggapan bahwa tentang semua yang terjadi dalam kehidupan seseorang berada dalam kendali orang itu sendiri. Kemampuan dalam mengendalikan keadaan dan bertanggung jawab terhadap suatu pekerjaan merupakan hal yang baik bagi seorang karyawan. Seseorang dengan internal locus of control sering menunjukan tingkat motivasi performa kerja, dan kepuasan kerja yang cukup baik. Temuan tersebut dapat menunjukan bahwa perusahaan sangat diuntungkan dengan tingkat kinerja yang tinggi dari seorang karyawan yang memiliki tingkat internal locus of control yang tinggi. Orang yang memiliki internal locus of control dominan memiliki performa tugas yang baik dan memiliki kesuksesan karir. Sundjoto, (2017) menyatakan bahwa internal locus of control berpengaruh positif terhadap kinerja karyawan. Sundjoto, (2017) membuktikan bahwa seseorang dengan tingkat internal locus of control yang tinggi memiliki orientasi untuk mencapai kesuksesan yang tinggi pula. Berdasarkan uraian tersebut maka penulis mengajukan hipotesis sebagai berikut:

H3: Internal locus of control berpengaruh positif terhadap Kinerja karyawan

Crider dalam Sundjoto, (2017) menyatakan bahwa semangat yang tinggi merupakan ciri yang melekat pada orang dengan konsep internal locus of control yang dominan. Orang dengan internal locus of control merupakan orang yang yakin bahwa merekalah agen untuk pembuat keputusan bagi dirinya sendiri. Diferensiasi dari individu seperti jenis kepribadian dapat memunculkan keadaan totalitas pada karyawan. Penelitian ini mengajukan internal locus of control sebagai salah satu variabel yang berpengaruh dalam membentuk keadaan psikologis engaged pada karyawan. Karakter yang dimiliki oleh orang dengan kecenderungan internal locus of control yang tinggi mempunyai potensi yang memungkinkan karyawan tersebut mengalami engagement dalam kegiatan pengembangan untuk masa depan karirnya. Fleur, (2016) juga menyatakan bahwa internal locus of control mempunyai peran yang signifikan terhadap peningkatan employee engagement karyawan sehingga berdasarkan uraian tersebut penulis mengajukan hipotesis 4 yaitu :

H4: Internal locus of control berpengaruh positif terhadap employee engagement

Kahn dalam Rich et al., 2010) menyatakan orang yang berperan penuh dalam pekerjaanya merupakan orang yang ter-engaged. Orang tersebut mengekspresikan dirinya secara totalitas di tempat kerjanya baik secara kognitif, fisik, maupun emosi. Kondisi yang ter-engaged akan merasakan pekerjaanya sebagai sesuatu yang sangat berarti baginya. Dampak employee engagement bagi individu adalah timbulnya ikatan kuat secara emosional pada seseorang mencakup rasa empati pada rekan kerja dan fokus berperan penuh dalam pekerjaanya. Manfaat bagi perusahaan, Karyawan yang ter-engaged akan menitik beratkan perhatianya pada kepuasan pelanggan. Karyawan tersebut juga menunjukan tingginya tingkat komitmen afektif dan kehatihatian dalam bekerja (Shuck \& Wollard, 2010).

Christian, Garza, \& Slaughter (2011) menyatakan bahwa employee engagement memberikan peningkatan kinerja baik dari individu maupun perusahaan. Penelitian sejenis yang dilakukan oleh Ramadhan \& Sembiring, (2014) juga menunjukan bahwa employee engagement berpengaruh terhadap kinerja karyawan. Berdasarkan uraian diatas penulis mengajukan hipotesis yaitu :

H5: Employee engagement berpengaruh positif terhadap kinerja karyawan

Employee engagement dibuktikan mempunyai pengaruh mediasi pada hubungan personal resource (self efficacy dan model big five) terhadap kinerja karyawan(Bhatti et al., 2018). Personal resource lain seperti motivasi kerja otonom juga merupakan hal yang penting bagi perusahaan karena mampu meningkatkan kinerja karyawan (Manganelli, Landry, Forest, \& Carpentier, 2017) 
- (Wiedemann, 2016) membuktikan bahwa motivasi kerja otonom membentuk keadaan psikologis engagement pada karyawan. penelitian lain membuktikan bahwa employee engagement dapat meningkatkan kinerja seseorang (Rich et al., 2010) Penelitian-penelitian tersebut menunujukan adanya kemungkinan bahwa internal locus of control mempunyai hubungan tak langsung terhadap kinerja karyawan melalui employee engagement sebagai variabel mediasi sehingga penulis mengajukan hipotesis sebagai berikut:

H6: Employee engagement memediasi pengaruh motivasi kerja otonom terhadap kinerja Karyawan

Karatepe \& Aga, (2014) membuktikan adanya pengaruh mediasi dari employee engagement pada hubungan personality traits terhadap job outcomes. Berdasar riset tersebut penulis memprediksi adanya pengaruh mediasi employee engagement pada personality trait seperti internal locus of control terhadap kinerja karyawan yang merupakan salah satu job outcome yang sangat penting bagi perusahaan. Prediksi tersebut berdasar pada penelitian dilakukan oleh Fleur, (2016) menyatakan bahwa internal locus of control mempunyai hubungan yang signifikan terhadap employee engagement dan Rich et al., (2010) yang menyatakan employee engagement memiliki pengaruh signifikan terhadap kinerja karyawan. Dua penelitian tersebut mengindikasikan adanya peran dari employee engagement dalam memediasi pengaruh internal locus of control terhadap kinerja karyawan. Berdasarkan uraian diatas penulis mengajukan hipotesis.

H7: Employee engagement memediasi pengaruh internal locus of control terhadap kinerja karyawan

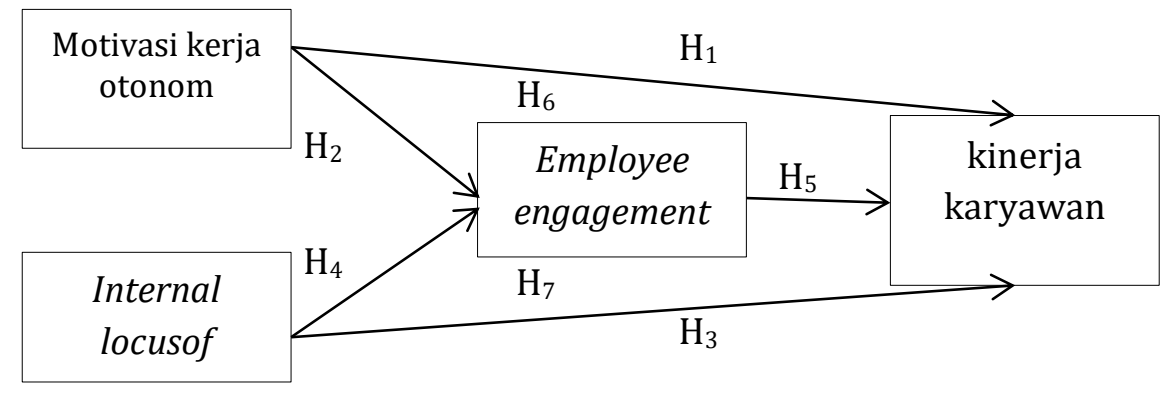

Gambar 1. Model penelitian

\section{METODE PENELITIAN}

Penelitian ini menggunakan metode survei terhadap karyawan Perusahaan Daerah Air Minum (PDAM) Tirta Satria Kabupaten Banyumas. Penelitian ini menggunakan jenis metode nonprobability sampling dengan teknik purposive sampling. Teknik purposive sampling adalah teknik pengambilan sampel dengan pertimbangan tertentu (Sugiyono, 2016). Purposive sampling digunakan karena variabel employee engagement mensyaratkan responden dengan kriteria tertentu yang tidak dimiliki oleh semua karyawan di PDAM. Kriteria yang digunakan dalam menentukan sampel adalah (1) status pekerjaan sebagai karyawan yang tetap (2) masa kerja karyawan yang mencapai 3 tahun. Dan (2017) menyatakan bahwa karyawan dengan masa kerja 3 tahun atau lebih merupakan karyawan yang sudah mengalami masa orientasi terhadap perusahaan dan bersiap untuk menjejaki karir yang profesional. Sehingga, karyawan dengan kriteria tersebut sudah dapat memberikan penilaian terhadap tingkat engagement yang mereka rasakan. Hal tersebut tentu saja mendukung validitas dan reliabilitas instrumen yang digunakan.

Berdasarkan kriteria tersebut, penulis menentukan sampel 92 Karyawan tetap yang dipilih adalah berasal dari populasi karyawan tetap PDAM Tirta Satria. Teknik pengumpulan data 
menggunakan kuisioner. Kuisioner yang digunakan berisi pertanyaan terkait motivasi kerja otonom, internal locus of control, employee engagement dan kinerja karyawan PDAM Tirta Satria dengan skala Likert 7 yang mana nilai tertinggi atau sangat setuju (SS) bernilai 7 dan nilai terendah atau Sangat Tidak Setuju (STS) bernilai 1.

Pengukuran variabel mengacu pada item-item pernyataan yang telah digunakan pada penelitian sebelumnya. Kinerja karyawan diukur dengan 10 item yang dikembangkan oleh Mathis dan Jackson yang diadopsi oleh Ramadhan dan Sembiring (2014), Motivasi kerja otonom diukur menggunakan 8 item yang dikembangkan oleh Deci dan Ryan yang diadopsi oleh Wiedemann (2016), Internal locus of control diukur menggunakan 6 item yang dikembangkan oleh Crider dalam Sundjoto (2017) dan employee engagement diukur menggunakan 18 item yang dikembangkan oleh Kahn yang diadopsi oleh Rich, Lepine dan Crawford (2010).

\section{HASIL DAN PEMBAHASAN}

Responden laki-laki sebanyak 55 (59,7\%) dan perempuan 37 (40,3\%) maka dapat disimpulkan bahwa responden laki-laki lebih dominan. Rentang usia terbesar yakni lebih dari 60\% karyawan yang bekerja di PDAM Tirta Satria berada pada rentang umur 26-40 tahun dimana usia tersebut merupakan usia yang tergolong produktif.

Berikut adalah statistik deskriptif dari semua variabel:

Tabel 1. Statistik Deskriptif

\begin{tabular}{lcccc}
\hline Variabel & Minimum & Maximum & Mean & Std. Deviation \\
\hline Kinerja Karyawan & 3.00 & 7.00 & 6.01 & .658 \\
Motivasi Kerja Otonom & 3.00 & 7.00 & 5.81 & .746 \\
Internal locus of control & 4.00 & 6.00 & 6.00 & .653 \\
Employee Engagement & 3.00 & 7.00 & 5.82 & .808 \\
\hline
\end{tabular}

Berdasarkan tabel diatas diperoleh bahwa rata-rata tertinggi ada pada kinerja karyawan $(6,01)$ hal tersebut berarti karyawan PDAM Tirta Satria senantiasa berusaha melaksanakan tugas dengan baik demi mencapai tingkat kinerja yang tinggi. Variabel Motivasi kerja Otonom memiliki nilai rata-rata (5.81) termasuk dalam kategori tinggi sehingga rata-rata karyawan PDAM Tirta Satria memiliki motivasi kerja otonom yang tinggi. Keseluruhan rata-rata pada variabel internal locus of control adalah $(6,00)$ yang menunjukan kecenderungan internal locus of control pada karyawan PDAM Tirta Satria sangat tinggi. Variabel employee engagement memiliki rata-rata 5,82 dari keseluruhan item sehingga dapat dikatakan bahwa tingkat employee engagament pada karyawan PDAM Tirta Satria tergolong tinggi.

\section{Analisis Hipotesis Analisis Regresi Berganda}

Tabel 2. Analisis Regresi Berganda

\begin{tabular}{|c|c|c|c|c|c|}
\hline \multirow{2}{*}{ no } & \multirow[t]{2}{*}{ Variabel } & \multicolumn{2}{|c|}{ Employee engagement } & \multicolumn{2}{|c|}{ Kinerja karyawan } \\
\hline & & $\mathrm{B}$ & Sig & $\mathrm{B}$ & Sig \\
\hline
\end{tabular}


Performance. Volume 26 Nomor 2 Tahun 2019, 66-76

\begin{tabular}{clcccc}
\hline 1 & $\begin{array}{l}\text { Motivasi kerja } \\
\text { otonom }\end{array}$ & 1,892 & 0,00 & 0,771 & 0,00 \\
2 & $\begin{array}{l}\text { Internal locus of } \\
\text { control }\end{array}$ & 2,484 & 0,00 & 1,034 & 0,00 \\
3 & $\begin{array}{l}\text { Employee } \\
\text { engagement }\end{array}$ & - & - & 0,335 & 0,00 \\
\hline
\end{tabular}

Berdasarkan hasil perhitungan regresi unstandarize coefficient sebesar 0,771 dan memiliki tingkat signifikansi 0,00. Berdasarkan hasil uji statistik tersebut, berarti variabel motivasi kerja otonom yang ada pada karyawan PDAM Tirta Satria memiliki pengaruh positif terhadap kinerja mereka sebesar 0,771. Hal tersebut menjelaskan bahwa apabila karyawan PDAM Tirta Satria memiliki tingkat motivasi kerja otonom yang tinggi maka kinerja mereka akan meningkat sehingga dalam hal ini dapat disimpulkan bahwa hipotesis pertama pada penelitian ini diterima.

Hasil uji analisis regresi pengaruh motivasi kerja otonom terhadap employee engagement menunjukkan nilai unstandarize coefficient sebesar 1,892 dan memiliki nilai signifikansi 0,00. Hasil tersebut menyatakan bahwa motivasi kerja otonom berpengaruh positif terhadap employee engagement sehingga apabila karyawan PDAM Tirta Satria memiliki tingkat motivasi kerja otonom yang tinggi maka akan meningkatkan engagement level mereka. Berdasarkan keterangan tersebut dapat di ambil kesimpulan bahwa hipotesis kedua diterima.

Analisis regresi yang dilakukan pada internal locus of control terhadap kinerja karyawan pada penelitian ini menunjukan nilai unstandarize coefficient sebesar 1,034 dengan tingkat signifikan 0,00. Berdasarkan hasil tersebut maka internal locus of control berpengaruh positif terhadap kinerja karyawan dengan nilai 1,034 sehingga karyawan PDAM Tirta Satria yang memiliki kecenderungan internal locus of control memiliki kinerja yang baik pula. Hasil tersebut dapat dijadikan dasar untuk mengambil kesimpulkan bahwa hipotesis ketiga diterima.

Pengujian pengaruh internal locus of control terhadap employee engagement menghasilkan tingkat unstandarized coefficient sebesar 2,484 dengan tingkat signifikansi 0,00 sehingga internal locus of control memiliki pengaruh positif terhadap employee engagement. Hal tersebut berarti setiap karyawan PDAM Tirta Satria yang memiliki kecenderungan internal locus of control yang dominan akan mempunyai tingkat engagement yang tinggi pula. Berdasarkan hasil tersebut maka hipotesis keempat pada penelitian ini diterima.

Hipotesis kelima : employee engagement berpengaruh positif terhadap kinerja.

Analisis regresi hubungan employee engagement terhadap kinerja menunjukkan nilai unstandarized coefficient sebesar 0,335 dengan nilai signifikansi 0,00. Hal tersebut menunjukkan bahwa employee engagement memiliki pengaruh positif terhadap kinerja karyawan sehingga karyawan PDAM Tirta Satria yang mengalami engagement akan mempunyai kinerja yang baik. Berdasarkan hal tersebut dapat disimpulkan bahwa hipotesis kelima diterima.

\section{Analisis Mediasi menggunakan product of coefficient}

Perhitungan analisis regresi dari motivasi kerja otonom terhadap kinerja karyawan memiliki nilai unstandarized coefficient senilai 0,771 dengan tingkat signifikansi 0,00. Hasil regresi dari variabel motivasi kerja otonom terhadap employee engagement memiliki nilai unstandarized coefficient 1,892 dengan nilai signifikansi 0,00. Analisis selanjutnya variabel mediasi dimasukkan dalam hal ini adalah employee engagement kedalam analisis regresi motivasi kerja otonom terhadap kinerja. Analisis tersebut menghasilkan pengaruh motivasi penurunan pada unstandarized coefficient dari motivasi kerja otonom namun tidak menjadi $0\left(c^{\prime} \neq 0\right)$ yaitu dari 0,771 menjadi 0,301 dengan nilai signifikansi 0,006 sehingga masih lebih kecil dari tingkat signifikansi.

Berdasarkan hasil perhitungan diperoleh $a=1,892 ; b=0,248 ; c^{\prime}=0,301$. Pengujian selanjutnya menggunakan product of coefficient adalah sebagai berikut: 
$S_{a b=\sqrt{0,248^{2} .0,181^{2}+1,892^{2} 0,042^{2}+0,181^{2} 0,042^{2}}}$

$$
S_{a b=\sqrt{0,0083}}=0,091
$$

Nilai t koefisen ab adalah sebagai berikut :

$$
Z=\frac{0,469}{0,091}=5,123
$$

Berdasarkan hasil perhitungan pengaruh motivasi kerja otonom terhadap kinerja melalui employee engagement telah diperoleh nilai z hitung sebesar 5,123 lebih besar dari z tabel dengan signifikansi 0,05 yaitu 1,96 maka dapat disimpulkan bahwa berdasarkan uji product of coefficient, employee engagement memediasi hubungan motivasi kerja otonom terhadap kinerja karyawan sehingga dapat disimpulkan bahwa hipotesis 6 diterima secara parsial.

Analisis mediasi employee engagement dimasukkan kedalam analisis regresi internal locus of control terhadap kinerja sehingga menghasilkan penurunan unstandarized coefficient dari internal locus of control menjadi 0,373 dengan tingkat signifikansi 0,009. Berdasarkan hasil tersebut pengaruh internal locus of control tetap signifikan terhadap kinerja karyawan setelah dimasukkan variabel mediasi karena tingkat signifikansi menunjukkan nilai 0,009 tidak melebihi

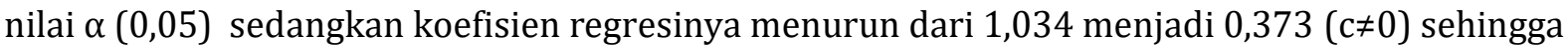
dapat dapat dikatakan employee engagement memediasi secara parsial hubungan internal locus of control terhadap kinerja karyawan sehingga hasil tersebut menunjukkan bahwa hipotesis ketujuh diterima secara parsial. Berdasarkan hasil perhitungan diperoleh $a=2,484 ; b=0,226$; $c^{\prime}=0,373$. Pengujian selanjutnya menggunakan product of coefficient adalah sebagai berikut:

$$
\begin{gathered}
S_{a b=\sqrt{b^{2} s a^{2}+a^{2} s b^{2}+s a^{2} s b^{2}}} \\
S_{a b=\sqrt{0,266^{2} .0,283^{2}+2,484^{2} 0,038^{2}+0,283^{2} 0,038^{2}}} \\
S_{a b=\sqrt{0,014}}=0,121
\end{gathered}
$$

Nilai t koefisen ab adalah sebagai berikut :

$$
Z=\frac{0,660}{0,121}=5,541
$$

Berdasarkan hasil perhitungan kedua yaitu pengaruh internal locus of control terhadap kinerja karyawan melalui employee engagement nilai z hitung sebesar 5,541 lebih besar dari z tabel dengan signifikansi 0,05 yaitu 1,96 maka dapat di simpulkan bahwa uji product of coefficient membuktikan employee engagement memediasi hubungan internal locus of control terhadap kinerja karyawan secara parsial sehingga hasil tersebut mendukung hipotesis 7.

\section{KESIMPULAN DAN IMPLIKASI Kesimpulan}

Berdasarkan hasil penelitiann ini maka dapat di ambil kesimpulan (1) Motivasi kerja otonom berpengaruh positif terhadap kinerja karyawan PDAM Tirta Satria Kabupaten Banyumas. (2) Motivasi kerja otonom berpengaruh positif terhadap employee engagement karyawan PDAM Tirta Satria Kabupaten Banyumas. (3) Internal locus of control memiliki pengaruh positif terhadap kinerja karyawan PDAM Tirta Satria Kabupaten Banyumas. (4) Inetrnal locus of control memiliki pengaruh positif terhadap employee engagement karyawan PDAM Tirta Satria Kabupaten Banyumas. (5) Employee engagement berpengaruh positif terhadap kinerja karyawan 
PDAM Tirta Satria Kabupaten Banyumas. (6) Employee engagement memediasi pengaruh positif motivasi kerja otonom terhadap kinerja karyawan PDAM Tirta Satria Kabupaten Banyumas. (7) Employee engagement memediasi pengaruh positif motivasi kerja otonom terhadap kinerja karyawan PDAM Tirta Satria Kabupaten Banyumas.

\section{Implikasi}

Kesimpulan pada penelitian ini menunjukkan bahwa pengaruh dari variabel internal locus of control memiliki peran yang paling tinggi dalam meningkatkan kinerja karyawan diantara variabel lainnya. Variabel tersebut perlu diperhatikan oleh pihak manajerial khususnya bidang pengembangan sumberdaya manusia karena tingkat internal locus of control merupakan karakter yang tertanam pada diri karyawan. Peran mediasi dari employee engagement pada analisis hubungan internal locus of control terhadap kinerja juga cukup besar sehingga pihak manajerial PDAM Tirta Satria dianjurkan untuk menciptakan kondisi employee engagement dikalangan karyawan. Berdasarkan kesimpulan tersebut, maka penulis memberikan beberapa saran kepada pihak manajerial PDAM Tirta Satria terkait program peningkatan kinerja dengan mengoptimalkan potensi internal locus of control dan employee engagement karyawan. Saran serta rekomendasi penulis adalah sebagai berikut:

Bidang pengembangan sumberdaya manusia dapat menerapkan program pengembangan karakter untuk menstimulasi internal locus of control pada karyawan. Behavioral modelling tentang perilaku kerja keras, semangat dalam bekerja, penyelesaian masalah seputar tugas dan model yang mencirikan karakter internal locus of control lainnya dapat menjadi salah satu metode yang digunakan untuk memberikan gambaran kepada karyawan bagaimana cara mereka melaksanakan tugas. Para kepala bagian dapat memberikan intrinsic reward berupa pengakuan atas prestasi karyawan dalam melaksanakan tugas. Pengakuan atas kemampuan pada karyawan akan membuat karyawan merasa percaya diri sehingga mereka akan merasa puas dengan pekerjaannya. Pihak manajerial juga dapat membudayakan rasa senang terhadap pekerjaan dengan cara menciptakan iklim kompetitif yang sehat antar karyawan misalnya dengan memberikan penghargaan terhadap karyawan yang memiliki kinerja yang paling baik dari masing-masing bidang perusahaan.

\section{Keterbatasan}

Penelitian ini hanya menganalisis faktor-faktor personal yang ada pada karyawan sehingga lingkup penelitian ini masih dalam skala individual. Penelitian ini menggunakan pernyataanpernyataan tertutup pada proses pengambilan data sehingga informasi-informasi yang didapatkan tebatas dan tidak bisa ditelusur lebih luas untuk kepentingan pengembangan penelitian Penelitian ini dilaksanakan pada perusahaan BUMD yang mana iklim bisnisnya relatif rendah dari persaingan sedangkan variabel employee engagement sangat berpotensi mempunyai pengaruh yang menguntungkan bagi perusahaan yang beroprasi di lingkungan bisnis yang ketat akan persaingan. Variabel employee engagement merupakan variabel multidimensional sehingga perlu untuk melakukan observasi lebih dalam tentang variabel ini. Survei pada penelitian ini dilakukan kepada karyawan sehingga informasi yang diperoleh merupakan informasi yang berasal dari satu sudut pandang yakni karyawan PDAM Tirta Satria. 


\section{DAFTAR PUSTAKA}

Amalini, H. F., Musadieq, M. Al, \& Afrianty, T. W. (2016). Pengaruh Locus Of Control Terhadap Kepuasan Kerja dan Kinerja ( Studi pada Karyawan Perusahaan Daerah Air Minum ( PDAM ) Kota Malang ). Jurnal Administrasi Bisnis, 35(1), 68-77.

Bhatti, M. A., Alshagawi, M., \& Juhari, A. S. (2018). Mediating the role of work engagement between personal resources ( self-efficacy, the big five model ) and nurses ' job performance. International Journal of Human Rights in Healthcare,. https://doi.org/10.1108/IJHRH-10-2017-0056.

Chen, J.C.\& Silverthrone, C. (2008) The impact of locus of control on job stress, job performance and job satisfaction in Taiwan. Leadership \& Organization Development Journal.29.572582.DOI 10.1108/01437730810906326.

Christian, M. S., Garza, A. S., \& Slaughter, J. E. (2011). Work engagement: A quantitative review and test of its relations with and contextual performance. Personnel Psychology, (64), 89-136. https://doi.org/10.1111/j.1744-6570.2010.01203.x

Dan, H. (2017). Future of work. Retrieved December 16, 2018, from www.quantumworkplace.com/futureof-work/the-tenure-curve-how-tenure-impacts-employee-engagement.

Deci, E. L., Olafsen, A. H., \& Ryan, R. M. (2017). Self-Determination Theory in Work Organizations : The State of a Self-Determination Theory in Work Organizations : The State of a Science. The Annual Review of Organizational Psychology and Organizational Behavior, 20-43. https://doi.org/10.1146/annurev-orgpsych-032516-113108.

Fleur, de L. (2016). The effect of work locus of control on the relationship between inclusive leadership and work engagement. Tilburg University.

Ghaffari, S.,Ishak, M.S., Burgoyne, J.,Nazri, M., \& Salleh, J.R (2017). The Influence of Motivation on Job Performance: A Case Study at Universiti Teknologi Malaysia. Australian Journal of Basic and Applied Sciences. 11.92-99.

Guo, Lan.(2007). Self-Determination Theory Of Motivation and Performance Management Systems (doctoral dissertation).Washington State University. Tidak di publikasikan

Karatepe, O. M., \& Aga, M. (2014). Work Engagement as a Mediator of the Effects of Personality Traits on Job Outcomes : A Study of Frontline Employees Work Engagement as a Mediator of the Effects of Personality Traits on Job Outcomes: A Study of Frontline Employees. Services Marketing Quarterly, 33(4), 37-41. https://doi.org/10.1080/15332969.2012.715053.

Kahn, A. W. (1990) Psychological Conditions Of Personal Engagement and Disengagement at Work.Academy of Management Journal.33.692-724

Manganelli, L., Landry, A. T., Forest, J., \& Carpentier, J. (2017). Self-Determination Theory Can Help You Generate Performance and Well-Being in the Workplace : A Review of the Literature, (July 2018). https://doi.org/10.1177/1523422318757210.

Maslach, C., Schaufeli, W. B., \& Leiter, M. P. (2001). Job Burnout. Annu. Rev. Psychol, 52, 397-422.

Mihaela, P. L., Magdalena, S. M., \& Loredana, T. S. (2013). A study on the relation between locus of control and creative attitudes in the structure of didactic competence, 84, 1381-1385. https://doi.org/10.1016/j.sbspro.2013.06.760.

Ng, T. W. H., Sorensen, K. L., \& Eby, L. T. (2006). Locus of control at work : a meta-analysis. Journal of Organizational Behavior, 27, 1057-1087. https://doi.org/10.1002/job.

Ramadhan, N., \& Sembiring, J. (2014). PENGARUH EMPLOYEE ENGAGEMENT DI HUMAN CAPITAL CENTER, 47-58. 
Rich, B. L., Lepine, J. A., \& Crawford, E. R. (2010). Job Engagement: Antecedents And Effects on Job Performance. Academy OfManagement Journal 2010, 53(3), 617-635.

Rotter, J. B. (1966). Generalized expectancies for internal versus external control of reinforcement. Psychological Monographs. 80 - 609.

Shuck, B., \& Wollard, K. (2010). Human Resource Development Review. Human Resource Development Review, 9(1), 89-110. https://doi.org/10.1177/1534484309353560.

Sugiyono. (2016). Statistika Untuk Penelitian. Bandung: Alfabeta.

Sundjoto. (2017). The Role of Internal Locus of Control on Intrinsic Motivation and Employee Performance of Ceramic Company in East Java Sundjoto. IOSR Journal of Business and Management (IOSR-JBM), 19(7), 29-35. https://doi.org/10.9790/487X-1907072935.

Vosloban, R. I. (2012). The Influence of the Employee ' s Performance on the company 's growth - a managerial perspective. Procedia - Social and Behavioral Sciences, 3(12), 660-665. https://doi.org/10.1016/S2212-5671(12)00211-0.

Wiedemann, C. S. (2016). Investigating Employee Engagement through a Self- Determination Theory Framework. Crimson University. 